\title{
Filosofi Larangan Bunga dalam Kontrak Syariah
}

\author{
Nurjihad \\ Fakultas Hukum Universitas Islam IndonesiaYogyakarta \\ Jl. Tamansiswa No. 158 Yogyakarta \\ nurjihad@uii.ac.id
}

\begin{abstract}
This research discusses the problems as follows: First, what main principles acting as the legal source of sharia contract law are; and, second, what the philosophical basis of the prohibition of taking interest in sharia contract law is. The method used in this research is normative juridical. The legal materials used are primary and secondary materials. The method of the research is philosophical approach. This research concludes that first, religious practice principle/basis acts as the main foundation of the legal source of the sharia contract law, and other principles act as the supporting factors to complete it. The principles of goodness and justice have ultimate position as the elaboration of religious practice principle since the values of goodness and justice are the soul and objective in all contracts made by the related parties; second, the philosophical basis of the prohibition of taking interest is subject directly to Al Qur'an. The prohibition of taking interest in sharia contract is the manifestation of the equality between the capital owners, and the consequence to take the risks and results courageously and responsibly. The prohibition agrees with the principles of goodness and justice, where there is no action of taking side at one of the related parties that are involved in a contract which means that both parties are in the equal position.
\end{abstract}

Key words : Interest, sharia contract

\begin{abstract}
Abstrak
Penelitian ini mengangkat permasalahan, pertama, prinsip/asas apakah pokok yang menjadi sumber dalam hukum kontrak syariah? Kedua, apa landasan filosofis larangan bunga/riba dalam kontrak syariah? Metode yang digunakan dalam penelitian ini adalah yuridis normatif. Bahan hukum yang digunakan berupa bahan hukum primer dan sekunder. Metode pendekatannya filosofis (philosophy approach). Penelitian ini menyimpulkan, pertama, prinsip/asas ibahah merupakan landasan pokok yang menjadi sumber dalam hukum kontrak syariah, sedangkan asas lainnya merupakan pendukung dan melengkapi. Prinsip/asas kemaslahatan dan keadilan mempunyai kedudukan utama sebagai elaborasi dari asas ibahah karena nilai-nilai kemaslahatan dan keadilan merupakan ruh dan tujuan dalam setiap kontrak yang dibuat oleh para pihak; Kedua, Landasan filosofis larangan bunga/riba adalah bersumber langsung dari al-Qur'an. Larangan riba/bunga dalam kontrak merupakan perwujudan persamaan yang adil di antara pemilik harta (modal) dengan usaha, serta pemikulan resiko dan akibatnya secara berani dan penuh rasa tanggung jawab. Larangan tersebut sesuai dengan asas kemaslahatan dan keadilan, dimana didalamnya tidak memihak kepada salah satu pihak yang melaksanakan kontrak, melainkan keduanya berada pada posisi yang seimbang.
\end{abstract}

Kata kunci: Bunga, kontrak syariah 


\section{Pendahuluan}

Perkembangan hukum kontrak syariah dewasa ini semakin mendapatkan tempat dan perhatian, seiring dengan perkembangan perekonomian syariah. Keberadaan kontrak memang sangat dibutuhkan oleh manusia dalam upaya memfasilitisasi kepentingan dirinya yang tidak dapat dipenuhi sendiri, dan memerlukan bantuan pihak lain. Pada pokoknya kontrak yang didalamnya berisi aturan main untuk pemenuhan kepentingan masing-masing pihak tersebut diperlukan untuk meningkatkan kesejahteraan hidup manusia sebagai makhluk sosial. Sebagai makhluk sosial (zoon politikon) ${ }^{1}$, manusia dalam hidupnya selalu membutuhkan dan berhubungan dengan manusia lainnya dalam rangka mempertahankan eksistensinya.

Bisnis syariah yang dari waktu ke waktu terus meningkat, dibuktikan makin banyak dan besarnya lembaga keuangan syariah perbankan maupun non bank, telah menuntut penggunaan atau implementasi akad (kontrak) syariah yang mampu memenuhi kepentingan para pihak/pelaku bisnis. Perbedaan utama kontrak konvensional dengan kontrak syariah adalah penerapan prinsip hukum Islam (syariah) dalam isi kontraknya.

Dalam kontrak, selain mengacu pada asas umum dalam hukum Islam (muamalat) yaitu asas ibahah yang menyatakan bahwa segala sesuatu itu hukumnya boleh, kecuali ada dalil yang melarangnya, terdapat pula beberapa asas penting yang satu dengan lainnya saling berkaitan, yaitu: asas konsensualisme (the principle of consensualism, mabda' ar-Radhai'iyah), asas kekuatan mengikatnya kontrak (the principle of the binding force of contract) dan asas kebebasan berkontrak (the principle of freedom of contract, mabda' hurriyyah at-Ta'aqud). ${ }^{2}$

Asas konsensualisme pada pokoknya menyatakan bahwa pada dasarnya terjadinya hubungan hukum berupa perjanjian adalah berdasar kehendak atau kata sepakat para pihak tanpa perlu dipenuhinya persyaratan formal tertentu. Para pihak bebas berkehendak untuk membuat kontrak dengan siapapun, menentukan isi dan bentuk kontrak. Mereka bebas menyusun klausula-klausula dari kontrak tersebut

\footnotetext{
${ }^{1}$ Soediman Kartohadiprojo, Pengantar Tata Hukum Indonesia, Ghalia Indonesia, Jakarta, 1993, hlm. 23.

${ }^{2}$ Ridwan Khairandy, "Landasan Filosofis Kekuatan Mengikatnya Kontrak", dalam Jurnal Hukum, Edisi Khusus Vol. 18 Oktober 2011, hlm. 37. Lihat juga Syamsul Anwar, Hukum Perjanjian Syariah: Studi tentang Teori Akad Dalam Fikih Muamalat,: Raja Grafindo Persada, Jakarta, 2007, hlm. 84-87. Herlien Budiono, Asas Keseimbangan Bagi Hukum Perjanjian Indonesia, Citra Aditya Bakti, Bandung, 2006, hlm. 95.
} 
tanpa campur tangan pihak lain. Pembatasannya adalah selama hal itu tidak melanggar larangan sebagaimana yang diatur dalam al-Qur'an dan as-Sunnah. Campur tangan memang bisa lahir pula apabila berasal dari negara melalui peraturan perundang-undangan yang menetapkan ketentuan-ketentuan yang diperkenankan atau yang dilarang. Dapat pula berasal dari Pengadilan berupa putusan Pengadilan yang membatalkan klausul perjanjian atau seluruh perjanjian tersebut, atau berupa putusan yang berisi bahwa suatu perjanjian batal demi hukum. ${ }^{3}$

Selanjutnya kesepakatan tersebut menimbulkan kekuatan mengikat bagi para pihak untuk melaksanakan sebagaimana layaknya undang-undang (pacta sun servanda), yang oleh karenanya harus dipatuhi dan dihormati oleh para pembuatnya, karena kontrak tersebut merupakan undang-undang bagi mereka yang membuatnya. Asas kekuatan mengikatnya kontrak, merupakan landasan penting di dalam hukum kontrak bahwa orang harus mematuhi janji. Aspek inilah yang menjadi dasar bagi para pihak di dalam kontrak terikat atau wajib melaksanakan perjanjian. ${ }^{4}$ Di dalam al-Qur'an dan Hadis terdapat banyak perintah agar para pihak memenuhi janji. Dalam kaidah usul fikih, 'perintah itu pada asasnya menunjukkan wajib'. Oleh karenanya, janji itu bersifat mengikat dan wajib dipenuhi. ${ }^{5}$

Sebagaimana telah disinggung di atas, meskipun para pihak mempunyai kebebasan untuk menentukan isi maupun bentuk kontrak, bebas menyusun klausula-klausula untuk kepentingan mereka, namun kebebasan tersebut haruslah sesuai dan/atau tidak bertentangan dengan ketentuan/norma agama maupun undang-undang yang berlaku. Di dalam Al-Qur'an misalnya ada ketentuan bahwa para pihak dilarang melakukan transaksi yang mengandung unsur riba, begitupun di dalam BW maupun KUHP juga terdapat larangan perjudian.

Istilah riba dalam praktik bisnis, hampir tidak pernah ditemukan. Namun, istilah yang muncul secara eksplisit adalah bunga. Perdebatan pemikiran mengenai riba dan bunga menunjukkan kesamaan di antara keduanya. Riba dalam konsepsi sekarang ini telah berubah dan berevolusi berbentuk bunga.

${ }^{3}$ P. Lindawaty S.Sewu, Aspek Hukum Perjanjian Baku dan Posisi Berimbang Para Pibak Dalam Perjanjian Waralaba, Disertasi (S3) Program Doktor Ilmu Hukum Program Pascasarjana Universitas Katolik Parahyangan, Bandung, 2007, hlm. 17-18.

${ }^{4}$ Ridwan Khairandy, Op.Cit., hlm. 38.

${ }^{5}$ Syamsul Anwar, Op.Cit., hlm. 89. 
Sehubungan dengan hal tersebut, adalah sangat penting untuk mengetahui dan menelaah bagaimana prinsip-prinsip pokok dalam pelaksanaan kontrak syariah serta dasar-dasar filosofis apakah yang menjadi landasan larangan bunga dalam kontrak syariah.

\section{Rumusan Masalah}

Penelitian ini mengangkat permasalahan, pertama, prinsip/asas apakah pokok yang menjadi sumber dalam hukum kontrak syariah? Kedua, apa landasan filosofis larangan bunga/riba dalam kontrak syariah?

\section{Tujuan Penelitian}

Penelitian ini bertujuan untuk mengetahui, pertama, prinsip/asas pokok yang menjadi sumber dalam hukum kontrak syariah, kedua, landasan filosofis larangan bunga/riba dalam kontrak syariah.

\section{Metode Penelitian}

Penelitian ini menggunakan metode penelitian normatif. Bahan hukum yang digunakan berupa bahan hukum primer dan sekunder. Bahan hukum berupa bukubuku literatur, disertasi, jurnal yang relevan, tulisan-tulisan ilmiah, hasil seminar, penelitian terdahulu, internet, artikel, dan lain-lain. Dalam penelitian ini, bahanbahan yang terkumpul akan dianalisis secara kualitatif. Metode pendekatan yang digunakan adalah pendekatan filosofis (philosophy approach).

\section{Hasil Penelitian dan Pembahasan}

\section{Prinsip Kontrak Syariah}

Selain landasan normatif berupa ketentuan yang menjadi dasar dalam perjanjian, terdapat pula asas-asas hukum yang harus menjadi acuan. Bahkan aturan/ketentuan dimaksud disusun dengan berakar dan bertumpu pada suatu asas hukum, yaitu nilai-nilai yang diyakini benar dan adil. Kata asas sendiri menurut bahasa berasal 
dari kata Asasun (bahasa Arab), yang berarti dasar, basis, dan pondasi. Secara terminologis, asas adalah dasar atau sesuatu yang menjadi tumpuan berpikir atau berpendapat. Istilah lain yang mempunyai pengertian sama dengan kata asas adalah prinsip, yang punya makna dasar atau kebenaran yang menjadi pokok dasar berfikir, bertindak dan sebagainya. ${ }^{6}$ Jika kata asas dihubungkan dengan kata hukum, maka memiliki pengertian kebenaran yang dipergunakan sebagai tumpuan berfikir dan alasan pendapat, terutama dalam penegakan dan pelaksanaan hukum. ${ }^{7}$

Menurut Paul Scholten asas hukum adalah pikiran-pikiran dasar, yang terdapat di dalam dan di belakang sistem hukum, masing-masing dirumuskan dalam aturanaturan perundang-undangan dan putusan-putusan hakim, yang berkenaan dengan ketentuan-ketentuan dan keputusan-keputusan individual dapat dipandang sebagai penjabarannya. $^{8}$

Asas hukum dapat pula di artikan sebagai suatu hal yang dianggap oleh masyarakat hukum yang bersangkutan sebagai basic truth atau kebenaran asasi, sebab melalui asas-asas hukum itulah pertimbangan etis dan sosial masyarakat tercakup dalam hukum. Oleh karenanya, asas hukum menjadi sumber untuk menghidupi tata hukumnya dengan nilai-nilai etis, moral dan sosial masyarakatnya. ${ }^{9}$

Asas hukum bukanlah kaidah hukum yang kongkret melainkan pikiran dasar yang umum sifatnya yang melatarbelakangi ketentuan hukum yang terdapat dalam suatu peraturan hukum, yang mana asas dimaksud tidak dituangkan/dirumusan dalam pasal-pasal suatu peraturan. Meskipun ada pula asas hukum yang dirumuskan dalam peraturan kongkret, misalnya asas kebebasan berkontrak sebagaimana tercantum dalam rumusan Pasal 1338 ayat (1) KUHPerdata.

Berkaitan dengan hukum perjanjian/kontrak syariah dikenal beberapa asas hukum yang melandasinya. Fathurrahman Jamil mengemukakan adanya 6 (enam) asas, yaitu: asas kebebasan, asas persamaan atau kesetaraan, asas keadilan, asas kerelaan, asas kejujuran dan kebenaran, dan asas tertulis. ${ }^{10}$ Adapun Syamsul Anwar

\footnotetext{
${ }^{6}$ Departemen Pendidikan Nasional, Kamus Besar Bahasa Indonesia, Edisi 3, Balai Pustaka, Jakarta, 2002, hlm. 72 dan 896. Lihat juga Gemala Dewi, et.al, Hukum Perikatan Islam di Indonesia: Kencana, Jakarta, 2005, hlm. 30.

${ }^{7}$ Mohammad Daud Ali, Hukum Islam: Pengantar Imu Hukum dan Tata Hukum di Indonesia, Raja Grafindo Persada, Jakarta, 2000, hlm. 114. 119-120.

${ }^{8}$ J.J.H.Bruggink (alih bahasa: Arief Sidharta), Refleksi Tentang Hukum, Citra Aditya Bakti, Bandung, 1996, hlm.

${ }^{9}$ Satjipto Rahardjo, "Peranan dan Kududukan Asas-asas Hukum Dalam Kerangka Hukum Nasional”, Seminar dan Lokakarya Ketentuan Umum Peraturan Perundang-undangan, Jakarta, tgl. 19-20 Oktober 1988.

${ }^{10}$ Fathurrahman Jamil et.al., Hukum Perjanjian Syariah dalam Kompilasi Hukum Perikatan, Citra Adutya Bakti, Bandung, hlm. 249.
} 
menyebutkan ada 8 (delapan) asas, yaitu: asas ibahah, asas kebebasan ber-akad, asas konsensualisme, asas janji itu mengikat, asas keseimbangan, asas kemaslahatan, asas amanah dan asas keadilan. ${ }^{11}$

\section{Asas Ibahah (al-Ibahah)}

Asas ibahah merupakan asas umum hukum Islam dalam bidang muamalah, yang dirumuskan dengan adagium: "pada asasnya segala sesuatu itu boleh dilakukan sampai ada dalil yang melarangnya". Perjanjian yang dibuat oleh para pihak untuk kesejahteraan hidupnya, merupakan bagian dari kegiatan muamalah. Dalam perjanjian dimaksud berlaku kebolehan atau sah untuk dilakukan sepanjang tidak ada larangan tegas atas perbuatan hukum tersebut. ${ }^{12}$

\section{Asas kebebasan berkontrak (al-hurriyah)}

Asas ini merupakan mengajarkan bahwa kebebasan kehendak para pihak dalam mengadakan kontrak merupakan keniscayaan. Asas ini merupakan prinsip dasar dalam hukum kontrak. Para pihak bebas untuk membuat suatu perjanjian (freedom of making contract), baik menyangkut obyek maupun subyek perjanjian, serta bebas menentukan bagaimana cara penyelesaian sengketa yang timbul. ${ }^{13}$ Dasar hukum mengenai hal ini bersifat umum tertuang dalam al-Qur'an Surat al-Baqarah ayat 256 atau mengacu pada dalil sebagaimana tersebut dalam Surat al-Maidah ayat 1, serta hadis seperti: "Sabda Nabi Saw: orang-orang Muslim itu senantiasa setia kepada syarat-syarat (janji-janji) mereka" (HR al-Hakim dari Abu Hurairah). Dalam hukum Islam, asas ini dibatasi oleh ketentuan syariah khususnya terkait dengan akibat hukum yang ditimbulkan, atau dengan ungkapan lain kebebasan tersebut tidaklah mutlak. ${ }^{14}$ Pembatasan tersebut diantaranya sebagaimana disebut dalam Surat Ali-Imran ayat 29, yang artinya: “Wahai orang-orang yang beriman, janganlah kamu makan harta sesamamu dengan cara batil, kecuali dengan cara tukar-menukar berdasarkan perizinan timbal balik (kesepakatan) diantara kamu".

\footnotetext{
${ }^{11}$ Syamsul Anwar, Op.Cit., hlm. 83-92.

${ }^{12}$ Ibid., hlm. 83-84.

${ }^{13}$ Abdul Ghofur Anshori, Hukum Perjanjian Islam Di Indonesia (Konsep, Regulasi dan Implementasi), Gadjah Mada University Press, Yogyakarta, 2010, hlm. 32.

${ }^{14}$ Syamsul Anwar, Op.Cit., hlm. 86.
} 


\section{Asas Persamaan/Kesetaraan (al-Musawah)}

Asas ini menempatkan para pihak kedudukan (bargaining position) yang sama, sehingga dalam menentukan term and condition dari akad/ perjanjian mereka setara. ${ }^{15}$ Dasar hukum yang bersifat umum mengenai asas ini tertuang dalam surat al-Hujurat ayat 13, yang artinya: "Hai manusia, sesungguhnya Kami menciptakan kamu dari seorang laki-laki dan seorang perempuan dan menjadikan kamu berbangsa-bangsa dan bersuku-suku supaya kamu saling mengenal. Sesungguhnya orang yang paling mulia diantara kamu di sisi Allah ialah orang yang paling bertaqwa di antara kamu. Sesungguhnya Allah Maha Mengetahui lagi Maha Mengenal". Ketentuan tersebut menunjukkan bahwa setiap orang mempunyai kedudukan yang sama di depan hukum (equality before the law). Perbedaan kedudukannya (di sisi Allah) adalah derajat ketaqwaannya. Dalam hal ternyata terdapat kondisi yang menimbulkan ketidaksetaraan, maka negara (dengan undang-undang) dapat mengatur dan meluruskan kedudukan tersebut.

Hampir mirip dengan asas ini adalah asas keseimbangan (mabda' at-Tawazun fi al Mu'awadhah). Keseimbangan dimaksud adalah keseimbangan antara yang diberikan dengan apa yang diterima maupun keseimbangan dalam memikul risiko. ${ }^{16}$ Apabila terjadi ketidakseimbangan (yang mencolok), maka akad/perjanjian tersebut dapat dibatalkan. Asas keseimbangan dalam memikul risiko tercermin dalam larangan terhadap transaksi riba (Q.S. al-Baqarah : 275-279), dimana di dalamnya hanya debitor yang memikul segala risiko atas kerugian usaha, sementara kreditor bebas sama sekali dan bahkan tetap mendapat keuntungan prosentase tertentu meskipun usaha debitor merugi.

\section{Asas Keadilan (al-'Adalah)}

Keadilan merupakan tujuan yang hendak diwujudkan oleh hukum. ${ }^{17}$ Pelaksanaan asas ini dalam suatu perjanjian menuntut para pihak untuk melakukan yang benar dalam pengungkapan kehendak dan keadaan, memenuhi semua kewajibannya. ${ }^{18}$ Dasar hukum yang bersifat umum mengenai asas ini tertuang antara lain dalam surat al-Maidah ayat 8, yang artinya: "Berlakulah adil, karena adil itu lebih dekat kepada taqwa", begitu pula dalam surat al-Hadid ayat 25 yang artinya:

\footnotetext{
${ }^{15}$ Abdul Ghofur Anshori, Loc.Cit.

${ }^{16}$ Syamsul Anwar, Op.Cit., hlm. 90.

${ }^{17}$ Ibid., hlm. 92.

${ }^{18}$ Abdul Ghofur Anshori, Op.Cit., hlm. 33.
} 
“Sesungguhnya Kami telah mengutus Rasul-rasul Kami dengan membawa bukti-bukti yang nyata dan telah Kami turunkan bersama mereka al-Kitab dan neraca (keadilan) supaya manusia dapat melaksanakan keadilan". Keadilan berbeda dengan dengan persamaan, keadilan adalah keseimbangan antara berbagai potensi individu, baik moral ataupun materiil, antara individu dan masyarakat, dan antara masyarakat yang satu dengan lainnya yang berlandaskan syariah Islam. ${ }^{19}$

\section{Asas Konsensualisme (ar-Radha'iyyah)}

Asas ini menyatakan bahwa segala transaksi yang dilakukan haruslah atas dasar kerelaan antara para pihak, harus didasarkan pada kesepakatan bebas dari para pihak dan tidak boleh ada unsur paksaan, tekanan, penipuan, dan mis-statemen. ${ }^{20}$ Terjadinya suatu perjanjian cukup dengan tercapainya kata sepakat antara para pihak tanpa perlu dipenuhinya formalitas-formalitas tertentu. Dalil hukum mengenai asas ini selain tertuang dalam surat Ali-Imran ayat 29, juga dalam surat Ali-Imran ayat 4, yang artinya: “Kemudian jika mereka menyerahkan kepadamu sebagian dari mas kawin itu atas dasar senang hati (perizinan, consent), maka makanlah (ambillah) pemberian itu sebagai suatu yang sedap lagi baik akibatnya". Selain itu juga dalam Hadis Nabi yang diriwayatkan oleh Ibn Hibban dan Ibn Majah menyatakan Nabi bersabda: Sesungguhnya jual beli itu berdasarkan kata sepakat", dan kaidah hukum Islam yang berbunyi: "Pada asasnya perjanjian (akad) itu adalah kesepakatan para pihak dan akibat hukumnya adalah apa yang mereka tetapkan melalui janji" ${ }^{21}$

\section{Asas Kejujuran dan Kebenaran (ash-Shidq)}

Kejujuran merupakan ketentuan yang harus dilaksanakan manusia dalam perbuatan muamalat. Perselisihan akan muncul pada umumnya karena diawali adanya ketidakjujuran dari salah satu atau kedua belah pihak yang melaksanakan perjanjian. Kejujuran itu sendiri mengandung makna kebenaran yang harus ditegakkan. Perbuatan dimaksud dapat dikataan benar apabila memiliki manfaat bagi para pihak yang melaksanakan perikatan dan juga bagi masyarakat dan lingkungannya, sedangkan perbuatan yang mendatangkan madharat adalah dilarang 22 . Pelanggaran terhadap asas

\footnotetext{
${ }^{19}$ Yusuf Qardhawi (alih bahasa Didin Hafidhuddin, et al.), Peran Nilai dan Moral dalam Perekonomian Islam, Robbani Press, Jakarta, 1997, hlm. 396.

${ }^{20}$ Abdul Ghofur Anshori, Pokok-pokok Hukum Perjanjian Islam di Indonesia, Citra Media, 2006, Yogyakarta, hlm. 27.

${ }^{21}$ Syamsul Anwar, Op.Cit., hlm. 87-88.

${ }^{22}$ Gemala Dewi, et.al, Op.Cit., hlm. 37.
} 
ini akan merusak legalitas perjanjian. Dalil hukum mengenai asas ini tertuang dalam surat al-Ahzab ayat 70, yang artinya: " Hai orang-orang yang beriman, bertakwalah kamu kepada Allah, dan katakanlah dengan perkataan yang benar". Asas ini dapat pula disebut sebagai Asas Amanah. Asas ini menuntut para pihak agar amanah. Masing-masing pihak haruslah beritikad baik dalam bertransaksi dengan pihak lainnya dan tidak dibenarkan salah satu pihak mengeksploatasi ketidaktahuan pihak lainnya. Dalam perjanjian tertentu, seringkali penguasaan informasi mengenai obyek perjanjian berada pada salah satu pihak, dalam hal ini dituntut sikap amanah pada pihak yang menguasai untuk memberikan informasi yang sejujurnya kepada pihak lain yang tidak mengetahuinya. ${ }^{23}$

\section{Asas Tertulis (Al-Kitabah)}

Asas ini mengajarkan agar setiap perjanjian hendaknya dibuat secara tertulis. Meskipun tidak mempengaruhi sah-nya suatu perjanjian, namun memiliki kepentingan pembuktian apabila dikemudian hari terjadi persengketaan. Dalil hukum mengenai asas ini tertuang dalam surat al-Baqarah ayat 282, yang artinya: “ Wahai orang-orang yang beriman, jika kamu melakukan transaksi atas dasar hutang dalam waktu yang telah ditentukan maka tulislah. Hendaklah penulis di antaramu menulis dengan benar,...". Pembuatan perjanjian secara tertulis ini akan memberikan kebaikan dan tanggung jawab bagi para pihak. Dalam ayat tersebut juga mengajarkan agar perjanjian yang dibuat secara tertulis itu disertai adanya saksi. Asas ini selain mempunyai fungsi mengatur dengan baik dan adil dalam hal terjadinya persengkataan, juga berfungsi mencegah para pihak untuk tidak bertanggungjawab atas perjanjian yang mereka buat.

\section{Asas Kekuatan Mengikat Perjanjian}

Asas ini mengajarkan bahwa akad/perjanjian yang dibuat oleh para pihak mengikat dan wajib dipenuhi. Dalam al-Qur'an dan Hadis cukup banyak perintah agar memenuhi janji yang dibuat. Sesuai kaidah usul fikih: "perintah itu pada asasnya menunjukkan wajib", berarti janji itu mengikat dan wajib dilaksanakan. Diantara dalil hukum mengenai asas ini selain sebagaimana tersebut dalam surat al-Maidah ayat 1 , juga tertuang dalam surat al-Israa' ayat 34, yang artinya: “... dan

\footnotetext{
${ }^{23}$ Syamsul Anwar, Op.Cit., hlm. 91.
} 
penuhilah janji, sesungguhnya janji itu akan dimintakan pertanggungjawabannya". Begitu juga hadis yang berbunyi, Nabi Saw bersabda: " Orang-orang Muslim itu senantiasa setia kepada syarat-syarat (janji-janji) mereka". ${ }^{24}$

\section{Asas Kemaslahatan}

Maksud dari asas ini adalah bahwa akad/perjanjian yang dibuat oleh para pihak bertujuan untuk mewujudkan kemaslahatan bagi mereka dan tidak boleh menimbulkan kerugian (madharat) atau keadaaan memberatkan (masyaqqah). Apabila dalam perjanjian terjadi perubahan keadaan yang tidak dapat diketahui sebelumnya serta membawa kerugian fatal bagi pihak yang bersangkutan sehingga memberatkannya, maka kewajibannya dapat diubah dan disesuaikan kepada batas yang masuk akal. ${ }^{25}$ Mengenai penerapan keadaan yang memberatkan, ada pendapat yang menyatakan melalui kesepakatan, melalui kehendak sepihak atau melalui hakim sesuai dengan keadaan masing-masing. Dalam hukum Islam kontemporer, seperti dituangkan ke dalam beberapa undang-undang hukum perdata yang berbasiskan prinsip syariah, penerapan keadaan yang memberatkan itu melalui hakim dengan cara pihak yang bersangkutan mengajukan permohonan pengurangan kewajibannya atas dasar keadaan yang memberatkan. ${ }^{26}$

Pada umumnya para ahli hukum menyebutkan ada 3 (tiga) asas pokok/fundamental yang melingkupi hukum kontrak, dimana satu dengan lainnya saling berkaitan yaitu: asas konsensualisme, asas kebebasan berkontrak dan asas kekuatan mengikatnya kontrak. Konsensualitas menyangkut terjadinya persetujuan, prinsip kekuatan mengikat menyangkut akibat persetujuan, sedangkan prinsip kebebasan berkontrak terutama berurusan dengan isi persetujuan.

Pandangan bahwa perjanjian sudah dilahirkan pada saat atau detik tercapainya konsensus atau kesepakatan, atau dengan perkataan lain perjanjian itu sah apabila hal-hal pokok sudah disepakati dan tidak perlu formalitas, ${ }^{27}$ merupakan perkembangan hukum dari tatanan hukum Romawi yang dimana persetujuan baru terjadi pada saat benda atau barang diserahkan. Pada awalnya hukum Romawi berpegang teguh pada persyaratan yang ketat bahwa persetujuan-persetujuan,

\footnotetext{
${ }^{24}$ Ibid., hlm. 89-90.

${ }^{25}$ Ibid.

${ }^{26}$ Ibid., hlm. 329.

${ }^{27}$ Subekti, Hukum Perjanjian, Intermasa, Jakarta, 1984, hlm. 15
} 
dengan beberapa kekeualian, harus memenuhi persyaratan-persyaratan tertentu untuk dapat dipandang sebagai persetujuan yang telah diadakan. ${ }^{28}$

Adapun asas kebebasan berkontrak di dalam sistem civil law dan common law lahir dan berkembang seiring dengan pertumbuhan aliran filsafat yang menekankan individualisme dan pasar bebas. Pada abad sembilan belas, kebebasan berkontrak sangat diagungkan baik oleh para filosuf, ekonom, sarjana hukum, maupun pengadilan. Pada saat itu, kebebasan berkontrak memiliki kecenderungan ke arah kebebasan tanpa batas (unrestricted freedom of contract). ${ }^{29}$ Dalam konteks sistem hukum Islam, pada mulanya kebebasan berkontrak tidak menjadi wacana sarjana hukum muslim. Kondisi demikian dipengaruhi kecenderungan tradisional mereka yang mengkategorisasikan transaksi yang diperbolehkan dan legal (halal), dan yang dilarang dan illegal (haram). Pada periode permulaan ada kerisauan terhadap semua kontrak yang bebas akan kekhawatiran riba dan uncertainty (gharar), dapat dikategorikan sebagai transaksi yang harus dibatalkan. ${ }^{30}$

Dalam perkembangan berikutnya, asas kebebasan berkontrak ini mendapatkan pembatasan dalam pemberlakuannya. Terdapat beberapa alasan yang menyebabkan perjanjian tidak lagi mengikat pihak-pihak yang membuatnya dalam hal terjadi kekhilafan (dwaling), paksaan (dwang), dan penipuan (bedrog), persetujuan tanpa sebab, atau dibuat karena sesuatu sebab yang palsu atau terlarang (Pasal 1321 jo. 1334 BW). Dengan demikian pandangan/ pemikiran kalangan sarjana hukum muslim yang memberikan pembatasan terhadap asas kebebasan berkontrak merupakan pandangan lama yang sesuai dan bertahan hingga kini.

Dalam perspektif hukum Islam, kontrak dilaksanakan pertama kali mengacu kepada asas ibahah yang merupakan asas umum hukum Islam dalam bidang muamalah. Asas ini mengajarkan bahwa segala sesuatu (perjanjian) itu diperbolehkan, kecuali ada dalil yang melarangnya. Dengan perkataan lain selama tidak ada dalil yang melarangnya, maka hukumnya boleh dilaksanakan. Beberapa dalil/ketentuan yang secara eksplisit diatur adalah pelarangan riba, perjudian (maisir), ketidakjelasan (gharar), haram dan zalim. Selama tidak melanggar ketentuan di atas, maka kegiatan tersebut dapat dikatakan sesuai dengan prinsip syariah.

\footnotetext{
${ }^{28}$ P.Lindawaty S.Sewu, Op.Cit., hlm. 71-72.

${ }^{29}$ Ridwan Khairandy, Op.Cit., hlm. 39-40.

${ }^{30}$ Ibid., hlm. 47.
} 
Riba merupakan penambahan pendapatan secara tidak sah (batil) antara lain dalam transaksi pertukaran barang sejenis yang tidak sama kualitas, kuantitas, dan waktu penyerahan $(f a d h l)$, atau dalam transaksi pinjam-meminjam yang mempersyaratkan pengembalian dana yang diterima melebihi pokok pinjaman karena berjalannya waktu (nasi'ah). Maisir adalah transaksi yang digantungkan kepada suatu keadaan yang tidak pasti dan bersifat untung-untungan. Adapun gharar merupakan transaksi yang objeknya tidak jelas, tidak dimiliki, tidak diketahui keberadaannya, atau tidak dapat diserahkan pada saat transaksi dilakukan kecuali diatur lain dalam syariah. Haram adalah transaksi yang objeknya dilarang dalam syariah, sedangkan zalim, yaitu transaksi yang menimbulkan ketidakadilan bagi pihak lainnya. ${ }^{31}$

Asas-asas lainnya merupakan asas pendukung yang sifatnya melengkapi serta merupakan elaborasi dan pengembangan dari asas ibahah. Asas konsensualisme, kebebasan berkontrak dan kekuatan mengikatnya kontrak, sebagaimana dikemukakan ahli hukum pada umumnya, memang merupakan asas yang pokok dan penting, khususnya dalam hukum kontrak non syariah. Namun dalam kontrak syariah, penting tidaknya asas yang melandasi sangat berkaitan juga dengan tujuan dari diadakannya akad/perjanjian itu sendiri. Menurut hukum Islam, sesungguhnya tujuan akad/perjanjian adalah mewujudkan akibat hukum yang pokok dari akad. Namun demikian tujuan akad berbeda dengan akibat hukum pokok akad. Perbedaannya terletak pada sudut mana melihatnya. Tujuan akad adalah maksud pokok yang hendak diwujudkan oleh para pihak, seperti memindahkan pemilikan atas suatu benda dengan imbalan dalam akad jual beli. Apabila maksud tersebut dapat direalisasikan sehingga terjadi perpindahan milik, maka perpindahan milik tersebut adalah akibat hukum pokok. Dengan perkataan lain, tujuan akad adalah maksud para pihak ketika membuat akad, sedangkan akibat hukum pokok adalah hasi yang dicapai ketika akad direalisasikan. ${ }^{32}$

Terealisasikannya akibat hukum pokok dari akad, pada intinya merupakan manifestasi dari kehendak sesungguhnya para pihak. Terpenuhinya kehendak tersebut maka didalamnya selain mengandung unsur kemaslahatan sekaligus keadilan yang diharapkan bagi para pihak. Dalam perspektif filsafat hukum Islam, keadilan dan kemaslahatan adalah merupakan tujuan yang dikehendaki. Salah satu konsep penting dan fundamental adalah konsep maqasid at-tasyri' atau maqasid al-syariah yang

\footnotetext{
${ }^{31}$ Lihat penjelasan Pasal 2 UU Nomor 21 Tahun 2008 Tentang Perbankan Syariah.

${ }^{32}$ Syamsul Anwar, Op.Cit., hlm. 219.
} 
menegaskan disyariatkannya hukum Islam adalah untuk mewujudkan dan memelihara maslahat umat manusia.

Berbagai asas atau prinsip yang berkembang dalam hukum kontrak merupakan sumber yang melatarbelakangi ketentuan hukum sekaligus menghidupi penerapan kontrak/perjanjian dalam sistem hukum yang berlaku, yang di dalamnya terkandung nilai-nilai kemaslahatan dan keadilan. Nilai-nilai kemaslahatan dan keadilan ini haruslah merupakan ruh dalam setiap kontrak yang dilakukan oleh para pihak. Dengan demikian asas kemaslahatan dan keadilan mempunyai kedudukan utama dalam kontrak syariah.

\section{Landasan Filosofis Larangan Bunga}

Secara normatif tidak pernah muncul secara eksplisit istilah riba sebagai sebuah sistem legal yang digunakan dalam bisnis atau perekonomian. Istilah yang muncul adalah bunga, yang mana di dalamnya mengandung substansi yang sama sebagai riba. Konsep riba sebenarnya telah lama dikenal dan mengalami perkembangan pemaknaan. Sebelum masuk peradaban Islam, kajian riba telah dibahas oleh kalangan agama Hindu, Budha, Yahudi, Yunani, Romawi dan Kristen. ${ }^{33}$

Konsep riba di kalangan Yahudi, yang dikenal dengan istilah "neshekh" dinyatakan sebagai hal yang dilarang dan hina. Pelarangan ini banyak terdapat dalam kitab suci mereka, baik dalam Old Testament (Perjanjian lama) maupun dalam undang-undang Talmud. Banyak ayat dalam Old Testament yang melarang pengenaan bunga pada pinjaman kepada orang miskin dan mengutuk usaha mencari harta dengan membebani orang miskin dengan riba. ${ }^{34}$ Sedangkan pada masa Yunani dan Romawi Kuno, praktek riba merupakan tradisi yang lazim berlaku. Pada masa Yunani sekitar abad VI SM hingga $1 \mathrm{M}$, terdapat beberapa jenis bunga yang bervariasi besarnya. Sementara itu, pada masa Romawi, sekitar abad V SM hingga IV M, terdapat undang-undang yang membolehkan penduduknya mengambil bunga selama tingkat bunga tersebut sesuai dengan tingkat maksimal yang dibenarkan hukum (maximum legal rate). ${ }^{35}$ Meskipun demikian, praktik pengambilan bunga tersebut dicela oleh para ahli filsafat Yunani, diantaranya Plato (427-347SM) dan Aristoteles (384-322SM), begitu pula para ahli filsafat

${ }^{33}$ Veithzal Rivai, et.al, Bank and Financial Institution Manajement Conventionaland Sharia System, RajaGrafindo Persada, Jakarta, 2007, hlm. 761. Lihat juga Muhammad Syafi'i Antonio, Bank Syari'ab: Dari Teori ke Praktik, Gema Insani Press, Jakarta, 2001, hlm. 42.

${ }^{34}$ Muhammad Syafi'i Antonio, Ibid., hlm. 43.

${ }^{35}$ Ibid. 
Romawi, seperti Cato (234-149SM), Cicero (106-43SM) dan Seneca (4SM-65 M) mengutuk praktik bunga, yang digambarkannya sebagai tindakan tidak manusiawi. ${ }^{36}$

Konsep riba di kalangan Kristen mengalami perbedaan pandangan, yang secara umum dapat dikelompokkan menjadi tiga periode sebagai berikut: ${ }^{37}$

Pertama, pandangan para pendeta awal Kristen (abad I-XII) yang mengharamkan riba dengan merujuk pada Kitab Perjanjian Lama dan undang-undang dari gereja. Pada abad IV M, gereja Katolik Roma melarang praktik riba bagi para pendeta, yang kemudian diperluas bagi kalangan awam pada abad V M. Pada abad VIII M, di bawah kekuasaan Charlemagne, gereja Katolik Roma mendeklarasikan praktik riba sebagai tindakan kriminal.

Kedua, pandangan para sarjana Kristen (abad XII-XVI) yang cenderung membolehkan bunga, dengan melakukan terobosan baru melalui upaya melegitimasi hukum, bunga dibedakan menjadi interest dan usury. Menurut mereka, interest adalah bunga yang diperbolehkan, sedangkan usury adalah bunga yang berlebihan. Para sarjana Kristen yang memberikan kontribusi pemikiran bunga ini adalah Robert of Courcon (1152-1218), William of Auxxerre (1160-1220), St. Raymond of Pennaforte (11801278), St. Bonaventure (1221-1274) dan St. Thomas Aquinas (1225-1274).

Ketiga, pandangan para reformis Kristen (abad XVI-1836) seperti Martin Luther (1483-1536), Zwingli (1454-1531), Bucer (1491-1551) dan John Calvin (1509-1564) yang menyebabkan agama Kristen menghalalkan bunga (interest). Pada periode ini, Raja Henry VIII memutuskan berpisah dengan Gereja Katolik Roma, dan pada tahun 1545 bunga (interest) resmi dibolehkan di Inggris asalkan tidak lebih dari 10\%. Kebijakan ini kembali diperkuat oleh Ratu Elizabeth I pada tahun 1571.

Perkembangan selanjutnya setelah itu, maka seluruh praktik operasionalisasi perbankan modern yang mulai tumbuh dan berkembang sejak abad XVI M menggunakan sistem bunga. Sistem bunga ini mulai tumbuh, mengakar, dan mendarah-daging dalam industri perbankan modern sehingga sulit untuk dipisahkan. Bahkan mereka beranggapan bahwa bunga adalah pusat berputarnya sistem perbankan. Jika tanpa bunga, maka sistem perbankan menjadi tak bernyawa dan akhirnya perekonomian akan lumpuh. ${ }^{38}$

\footnotetext{
${ }^{36}$ Abdul Azim Islahi, Economic Concepts of Ibn Taimiyah, The Islamic Foundation, London, 1988, hlm. 124.

${ }^{37}$ Anita Rahmawati, Riba Dalam Perspektif Kenangan Islam, hlm. 5-6, dalam http://p3m.stainkudus.ac.id/ files/ Anita.pdf

${ }^{38}$ Muhammad Abdul Mannan, Islamic Economic, Theory and Practice, terj. Nastangin, Dana Bhakti Wakaf, Yogyakarta 1997, hlm. 165.
} 
Sementara itu, riba telah jelas dan tegas dilarang dalam Islam. Pelarangan riba dalam Al-Qur' an tidak diturunkan sekaligus melainkan secara bertahap, sejalan dengan kesiapan masyarakat pada masa itu, seperti pelarangan minuman keras. Adapun tahaptahap pelarangan riba dalam Al-Qur'an dapat dijelaskan sebagai berikut: ${ }^{39}$

Tahap pertama, disebutkan bahwa riba akan menjauhkan kekayaan dari keberkahan Allah, sedangkan shodaqoh akan meningkatkan keberkahan berlipat ganda (QS. Ar-Rum: 39).

Tahap kedua, pada awal periode Madinah, praktik riba dikutuk dengan keras, sejalan dengan larangan pada kitab-kitab terdahulu. Riba dipersamakan dengan mereka yang mengambil kekayaan orang lain secara tidak benar dan mengancam kedua belah pihak dengan siksa Allah yang pedih (QS. An-Nisa':160-161).

Tahap ketiga, pelarangan riba dengan dikaitkan pada suatu tambahan yang berlipat ganda (QS. Ali Imron: 130). Ayat ini turun setelah perang Uhud yaitu tahun ke-3 Hijriyah. Istilah berlipat ganda harus dipahami sebagai sifat bukan syarat sehingga pengertiannya adalah yang diharamkan bukan hanya yang berlipat ganda saja sementara yang tidak berlipat ganda/sedikit maka tidak haram, melainkan sifat riba yang berlaku umum pada waktu itu adalah berlipat ganda.

Tahap keempat merupakan tahap terakhir di mana Allah dengan tegas dan jelas mengharamkan riba, menegaskan perbedaan yang jelas antara jual beli dan riba dan menuntut kaum Muslimin agar menghapuskan seluruh hutang-piutang yang mengandung riba (QS. Al-Baqarah: 278-279).

Secara etimologis, bunga dalam The American Heritage Dictionary of the English Language didefinisikan sebagai interest is a charge for a financial loan, usually a percentage of the amount loaned. ${ }^{40}$ Kata "interest" berasal dari bahasa Latin "intereo" yang berarti untuk kehilangan "to be lost". Sebagian lain mengatakan bahwa interest berasal dari bahasa Latin "interesee" yang berarti datang di tengah (to come in between) yaitu kompensasi kerugian yang muncul di tengah transaksi jika peminjam tidak mengembalikan sesuai waktu (compensation or penalty for delayed repayment of a loan). Pada perkembangan selanjutnya, "interest" bukan saja diartikan sebagai ganti rugi akibat keterlambatan pembayaran hutang, tetapi diartikan juga sebagai ganti rugi atas kesempatan yang hilang (opportunity loss). ${ }^{41}$

\footnotetext{
${ }^{39}$ Anita Rahmawati, Op.Cit., hlm. 6-7.

${ }^{40}$ Wirdyaningsih, et.al, Bank dan Asuransi Islam di Indonesia, Kencana, Jakarta, 2005, hlm. 21.

${ }^{41}$ Veithzal Rivai, et.al., Op.Cit., hlm 762. Lihat juga Adiwarman Karim, Bank Islam: Analisis Fiqh dan Kenangan, RajaGrafindo Persada, Jakarta, 2007, hlm. 42.
} 
Berbagai 'pembenaran' pemikiran teori mengenai bunga sebagai instrumen perekonomian yang penting banyak ditemukan. Di antaranya pemikiran teori bunga moneter yang terakhir dilakukan oleh Keynes. Ia memandang bahwa bunga bukan sebagai harga atau balas jasa atas tabungan, tetapi bersifat pembayaran untuk pinjaman uang. Secara umum teori bunga moneter memandang bahwa pembayaran bunga sebagai tindakan opportunitas untuk memperoleh keuntungan dan tindakan meminjamkan uang. Oleh karena itu, Keynes menyebutnya sebagai motif spekulasi. Motif ini didefinisikan sebagai usaha untuk menjamin keuntungan di masa yang akan datang. Dalam teori ini, aktivitas spekulasi yang dilakukan pelaku ekonomi akan mempengaruhi suku bunga dan silih berganti, dan akhirnya akan mempengaruhi investasi, tingkat produksi dan kesempatan kerja. ${ }^{42}$ Sementara itu, jelas dalam Islam melarang segala bentuk spekulasi karena aktivitas dapat dikategorikan sebagai maysir (gambling).

Pada kenyataannya berbagai teori bunga yang muncul sejumlah kelemahan yaitu tidak mampu menjelaskan secara pasti apakah bunga diperlukan dalam suatu perekonomian atau apakah bunga berperan mendorong investasi nyata dan bukan mendorong untuk berspekulasi. Oleh karena itu, gugatan kemudian mulai muncul berkenaan dengan teori bunga tersebut sampai akhirnya muncullah tawaran solusi alternatif dengan munculnya teori bagi hasil di perbankan syari'ah. ${ }^{43}$

Secara kelembagaan, telah cukup banyak fatwa ulama tentang pengharaman bunga bank baik dalam forum internasional, maupun nasional. Keputusan lembaga Islam internasional dimaksud antara lain: ${ }^{44}$ 1) Dewan Studi Islam al-Azhar, Kairo, dalam konferensi DSI al-Azhar pada bulan Muharram 1385 H/ Mei 1965 M, yang memutuskan bahwa "bunga dalam segala bentuk pinjaman adalah riba yang diharamkan"; 2) Keputusan Muktamar Bank Islam II, Kuwait, 1403 H/1983; 3) Majma' al-Figh al-Islami, Organisasi Konferensi Islam, dalam Keputusan No. 10 Majelis Majma' Fiqh Islami, pada Konferensi OKI ke-2 di Jeddah, Arab Saudi pada tanggal 10-16 Rabi' ats-Tsani 1406 H / 22-28 Desember 1985, yang memutuskan bahwa “seluruh tambahan dan bunga atas pinjaman yang jatuh tempo dan nasabah tidak mampu membayarnya, demikian pula tambahan (atau bunga) atas pinjaman dari permulaan perjanjian adalah dua gambaran dari riba yang diharamkan secara syari'ah; 4) Rabithah

\footnotetext{
${ }^{42}$ Muhamad, Teknik Perbitungan Bagi Hasil dan Profit Margin pada bank Syari'ah, UII Press, Yogyakarta, 2001, hlm. 14-15.

${ }^{43}$ Anita Rahmawati, Op.Cit., hlm. 15.

${ }^{44}$ Ascarya, Akad dan Produk Bank Syariah, RajaGrafindo Persada, Jakarta, 2007, hlm. 15.
} 
al-'Alam al-Islami, dalam keputusan No. 6 sidang ke-9 yang diselenggarakan di Mekkah tanggal 12-19 Rajab 1406 H, yang memutuskan bahwa "bunga bank yang berlaku dalam perbankan konvensional adalah riba yang diharamkan"; 5) Jawaban Komisi Fatwa al-Azhar pada 28 Februari 1988.

Sedangkan keputusan lembaga Islam nasional di Indonesia, antara lain: ${ }^{45} 1$ ) Muhammadiyah dalam Lajnah Tarjih tahun 1968 di Sidoarjo memutuskan bahwa "hukum bunga bank pemerintah adalah musytabihat; 2) Nahdhatul Ulama dalam Lajnah Bahsul Masa'il, Munas Bandar Lampung pada tahun 1992 mengeluarkan fatwa tentang bunga bank dengan mengakomodasi tiga keputusan, yaitu bunga bank adalah haram, halal dan syubhat; 3) Majelis Ulama Indonesia dalam Lokakarya Alim Ulama di Cisarua 1991 memutuskan bahwa a) bunga bank sama dengan riba; b) bunga bank tidak sama dengan riba; dan c) bunga bank tergolong syubhat. 4) Lajnah Ulama Komisi Fatwa se-Indonesia, Majelis Ulama Indonesia, pada Silaknas MUI pada 16 Desember 2003 memutuskan bahwa "bunga bank sama dengan riba"; 5) Keputusan Fatwa Majelis Ulama Indonesia Nomor 1 Tahun 2004 Tentang Bunga (Interest/Fa'idah); 6) PP Muhammadiyah, Fatwa Majelis Tarjih Muhammadiyah No. 8 pada bulan Juni 2006 diumumkan pada Rakernas dan Bussiness Gathering Majelis Ekonomi Muhammadiyah 19-21 Agustus 2006 memutuskan bahwa "bunga bank haram".

Fatwa di atas secara memastikan bunga sama dengan riba sehingga hukumnya dilarang. Pelarangan riba, menurut Qardhawi memiliki hikmah yang tersembunyi di balik pelarangannya, yaitu perwujudan persamaan yang adil di antara pemilik harta (modal) dengan usaha, serta pemikulan resiko dan akibatnya secara berani dan penuh rasa tanggung jawab. Prinsip keadilan dalam Islam ini tidak memihak kepada salah satu pihak, melainkan keduanya berada pada posisi yang seimbang. ${ }^{46}$ Lebih lanjut, menurut Maududi, praktik bunga telah merusak perekonomian masyarakat dikarenakan telah menahan kekayaan dan tidak membelanjakannya untuk membeli barang-barang masyarakat dan hasil produksinya dari pasar. ${ }^{47}$

Meskipun secara normatif larang riba/bunga sangatlah jelas dan tegas dalam al-Qur'an (Q.S. al-Baqarah: 275-281, Ali-Imran: 130), konsep pelarangan riba dalam Islam dapat dijelaskan dengan keunggulannya secara ekonomis dibandingkan dengan konsep ekonomi konvensional. Riba secara ekonomis lebih merupakan

\footnotetext{
${ }^{45}$ Ibid., hlm. 16.

${ }^{46}$ Anita Rahmawati, Op.Cit., hlm. 27.

${ }^{47}$ Abul A’la al Maududi (alih bahasa Abdullah Suhaili), Riba, Hudaya, Jakarta, 1970, hlm. 43.
} 
sebuah upaya untuk mengoptimalkan aliran investasi dengan cara memaksimalkan kemungkinan investasi melalui pelarangan adanya pemastian (bunga). Semakin tinggi tingkat suku bunga, semakin besar kemungkinan aliran investasi yang terbendung. Hal ini dapat diumpamakan seperti sebuah bendungan. Semakin tinggi dinding bendungan, maka semakin besar aliran air yang terbendung. ${ }^{48}$

Pelarangan riba atau bunga sangat jelas mempunyai implikasi pada sektor riil, yaitu: $\left.{ }^{49} 1\right)$ mengoptimalkan aliran investasi tersalur lancar ke sektor riil; 2) mencegah penumpukan harta pada sekelompok orang, ketika hal tersebut berpotensi mengeksploitasi perekonomian (eksploitasi pelaku ekonomi atas pelaku yang lain; eksploitasi sistem atas pelaku ekonomi);3) mencegah timbulnya gangguan-ganguan dalam sektor riil, seperti inflasi dan penurunan produktivitas ekonomi makro; 4) mendorong terciptanya aktivitas ekonomi yang adil, stabil dan sustainable melalui mekanisme bagi hasil (profit-loss sharing) yang produktif.

Di samping melarang praktik riba/bunga, di sisi lain Islam mendorong umatnya untuk melakukan investasi. Dalam hal ini, terdapat perbedaan mendasar antara antara investasi dan membungakan uang. Perbedaan tersebut dapat ditelaah dari definisi hingga maknanya masing-masing. Investasi adalah kegiatan usaha yang mengandung resiko karena berhadapan dengan unsur ketidakpastian. Dengan demikian, perolehan return-nya tidak pasti dan tidak tetap. Sedangkan membungakan uang adalah kegiatan usaha yang kurang mengandung resiko karena perolehan return-nya berupa bunga yang relatif pasti dan tetap. ${ }^{50}$

Dengan demikian jelas bahwa praktik riba/bunga sangatlah merugikan salah satu pihak dalam kontrak, dikarenakan terjadinya eksploitasi pelaku ekonomi atas pelaku yang lain dan eksploitasi sistem atas pelaku ekonomi. Pelarangan praktik ini bertujuan agar terwujud aktifitas ekonomi yang adil dan maslahat antara pemilik harta (modal) dengan usaha, serta pemikulan resiko dan akibatnya secara berani dan penuh rasa tanggung jawab.

\section{Penutup}

Dari kajian di atas dapat ditarik kesimpulan: pertama, prinsip/asas ibahah merupakan landasan pokok yang menjadi sumber dalam hukum kontrak syariah,

\footnotetext{
${ }^{48}$ Ascarya, Op.Cit., hlm. 17.

${ }^{49}$ Ibid., hlm. 19.

${ }^{50}$ Mohammad Syafi'i Antonio, Op.Cit., hlm. 59.
} 
sedangkan asas lainnya merupakan pendukung dan melengkapi. Prinsip/asas kemaslahatan dan keadilan mempunyai kedudukan utama sebagai elaborasi dari asas ibahah karena nilai-nilai kemaslahatan dan keadilan merupakan ruh dan tujuan dalam setiap kontrak yang dibuat oleh para pihak. Kedua, Landasan filosofis larangan bunga/riba adalah bersumber langsung dari Al-Qur'an. Larangan riba/ bunga dalam kontrak merupakan perwujudan persamaan yang adil di antara pemilik harta (modal) dengan usaha, serta pemikulan resiko dan akibatnya secara berani dan penuh rasa tanggung jawab. Larangan tersebut sesuai dengan asas kemaslahatan dan keadilan, dimana didalamnya tidak memihak kepada salah satu pihak yang melaksanakan kontrak, melainkan keduanya berada pada posisi yang seimbang.

\section{Daftar Pustaka}

A'la al Maududi, Abul (alih bahasa Abdullah Suhaili), Riba, Hudaya, Jakarta, 1970.

Abdul Mannan, Muhammad, Islamic Economic, Theory and Practice, terj.Nastangin, Dana Bhakti Wakaf, Yogyakarta, 1997.

Anwar, Syamsul, Hukum Perjanjian Syariah: Studi Tentang Teori Akad dalam Fikih Muamalat, Raja Grafindo Persada, Jakarta, 2007.

Ascarya, Akad dan Produk Bank Syariah, RajaGrafindo Persada, Jakarta, 2007.

Azim Islahi, Abdul, Economic Concepts of Ibn Taimiyah, London: The Islamic Foundation, 1988.

Budiono, Herlien, Asas Keseimbangan Bagi Hukum Perjanjian Indonesia, Citra Aditya Bakti, Bandung 2006.

Daud Ali, Mohammad, Hukum Islam:Pengantar Ilmu Hukum dan Tata Hukum di Indonesia, Raja Grafindo Persada, Jakarta, 2000.

Departemen Pendidikan Nasional, Kamus Besar Bahasa Indonesia, ed.3, Balai Pustaka, Jakarta 2002.

Dewi, Gemala, et.al, Hukum Perikatan Islam Di Indonesia, Kencana, Jakarta 2005.

Ghofur Anshori, Abdul, Hukum Perjanjian Islam Di Indonesia (Konsep, Regulasi dan Implementasi), Yogyakarta: Gadjah Mada University Press, 2010. , Pokok-pokok Hukum Perjanjian Islam di Indonesia, Citra Media, Yogyakarta 2006.

J.H.Bruggink, J., (alih bahasa: Arief Sidharta), Refleksi Tentang Hukum, Citra Aditya Bakti, Bandung, 1996.

Jamil, Fathurrahman et.al., Hukum Perjanjian Syariah dalam Kompilasi Hukum Perikatan, Citra Aditya Bakti, Bandung 2001. 
Karim, Adiwarman, Bank Islam: Analisis Figh dan Keuangan, RajaGrafindo Persada, Jakarta 2007.

Kartohadiprojo, Soediman, Pengantar Tata Hukum Indonesia, Ghalia Indonesia, Jakarta, 1993.

Khairandy, Ridwan, “Landasan Filosofis Kekuatan Mengikatnya Kontrak”, dalam Jurnal Hukum, Edisi Khusus Vol. 18 Oktober 2011.

Lindawaty S.Sewu, P., Aspek Hukum Perjanjian Baku dan Posisi Berimbang Para Pihak Dalam Perjanjian Waralaba, Disertasi (S3) Program Doktor Ilmu Hukum Program Pascasarjana Universitas Katolik Parahyangan, Bandung, 2007.

Muhamad, Teknik Perhitungan Bagi Hasil dan Profit Margin pada bank Syari'ah, UII Press, Yogyakarta, 2001.

Qardhawi, Yusuf (alih bahasa Didin Hafidhuddin, et al.), Peran Nilai dan Moral dalam Perekonomian Islam, Robbani Press, Jakarta, 1997.

Rahardjo, Satjipto, "Peranan dan Kududukan Asas-asas Hukum dalam Kerangka Hukum Nasional", Seminar dan Lokakarya Ketentuan Umum Peraturan Perundangundangan, Jakarta: 19-20 Oktober 1988.

Rahmawati, Anita, Riba dalam Perspektif Keuangan Islam, http://p3m.stainkudus. ac.id/files/Anita.pdf

Rivai, Veithzal, et.al, Bank and Financial Institution Manajement Conventionaland Sharia System, RajaGrafindo Persada, Jakarta, 2007.

Subekti, Hukum Perjanjian, Intermasa, Jakarta, 1984.

Syafi'i Antonio, Muhammad, Bank Syari'ah: Dari Teori ke Praktik, Gema Insani Press, Jakarta, 2001.

Wirdyaningsih, et.al, Bank dan Asuransi Islam di Indonesia, Kencana, Jakarta 2005.

Undang Undang Nomor 21 Tahun 2008 Tentang Perbankan Syariah. 